\title{
PERAMALAN INDEKS TARIF ANGKUTAN PELAYARAN CURAH KERING
}

\author{
Forecasting the Drybulk Freight Index
}

Oleh:

Anton Ferdiansyah ${ }^{1^{*}}$, Luky Adrianto ${ }^{2}$, Bagus Sartono ${ }^{3}$, Deni Achmad Soeboer ${ }^{4}$

${ }^{1}$ Mahasiswa Sekolah Bisnis, Institut Pertanian Bogor

${ }^{2}$ Pengajar Fakultas Perikanan dan Ilmu Kelautan, Institut Pertanian Bogor

${ }^{3}$ Pengajar Fakultas Matematika dan Ilmu Pengetahuan Alam, Institut Pertanian Bogor

${ }^{4}$ Staf Pengajar Program Studi Teknologi Perikanan Laut, Sekolah Pascasarjana Institut Pertanian Bogor

*Korespondensi: antonf.jr@gmail.com

\begin{abstract}
ABSTRAK
Volatilitas dan risiko tinggi merupakan ciri khas dari pasar tarif pelayaran curah kering. Ditenggarai hal ini dikarenakan banyaknya ketidakpastian yang mempengaruhinya, mulai dari kondisi ekonomi dunia, guncangan politik, kemajuan teknologi, hingga sensitivitas terhadap sentimen pasar. Banyak akademisi yang memberikan perhatian dan berusaha untuk memahami fenomena ini. Beberapa kajian telah ditulis dan salah satunya adalah mengenai hubungan peramalan sebagai alat yang bisa mengurangi risiko ketidakpastian. Oleh karena itu makalah ini mencoba untuk meramalkan indeks tarif angkutan pelayaran curah kering (BDI) dengan menggunakan pendekatan ekonometrik berdasarkan data pada pasar tarif angkutan curah kering selama periode 1991 sampai 2016. Penelitian ini diawali dengan menjelaskan karakteristik dan gambaran umum dari pasar tarif curah kering dan faktor penentu yang mempengaruhi permintaan dan penawaran pasar juga diidentifikasi dan dianalisa. Variabel yang signifikan diperoleh melalui tinjauan literatur, dan juga beberapa model ekonomi dari penelitian terdahulu juga dipelajari, sehingga berdasarkan pada hal-hal tersebut pondasi dari permodelan dapat dilakukan. Indikator ekonomi yang ditunjukkan oleh GDP dunia digunakan untuk memprediksi volume perdagangan curah kering melalui laut, bersama rerata jarak, kedua variabel tersebut terpilih sebagai faktor penentu dari dari sisi permintaan. Sementara armada kapal curah kering dan harga bahan bakar dijadikan faktor penentu dari sisi penawaran. Regresi Linier dipergunakan untuk membuat model ekonometrik guna meramalkan tingkat harga di pasar tarif ke depannya. Dari peramalan menunjukkan jika pertumbuhan armada kapal tetap mengikuti tren yang ada, maka indeks tarif angkutan curah kering akan sulit naik dan kembali ke titik normalnya.
\end{abstract}

Kata kunci: Baltic Dry Index (BDI), Model Ekonometrik, Pasar Tarif Angkutan Curah Kering, Peramalan tarif angkutan pelayaran, dan Permintaan Penawaran Pelayaran.

\begin{abstract}
Volatility and high risk is specific characteristic of the drybulk freight market. Many experts believe this is due to the that affect it. Ranging from world economy, political shock, technology, to the sensitive market sentiments. Therefore many academics are concern and trying to understand this phenomenon. A lot of research has been conducted and one of them was related to the forecasting the drybulk freight as a tool to reduce the risk of uncertainty, under this circumstances, this paper makes an attempts to forecast the drybulk freight index (BDI) using an econometric model based on data from the drybulk freight market over the period from 1991 to 2016 . This research begins by describing the characteristics and general features of the dry bulk tariff market and the
\end{abstract}


determinants affecting market demand and supply are also identified and analyzed. Significant variables were obtained through literature review, and also some of the economic models from previous studies were also studied. Based on these literatures review the foundations of the modeling can be performed. The economic indicator shown by world GDP is used to predict the dry bulk trade volume by sea, along with the average distance, the two variables are selected as determinants from the demand side. While the fleet of dry bulk carriers and fuel prices are the determinants from the supply side. Linear Regression is used to create econometric models to predict price levels in tariff markets in the future. From forecasting indicates if the growth of the fleet remains in accordance with the existing trends, the dry bulk freight rate index will be difficult to rise and back to their normal point.

Keywords: Baltic Dry Index (BDI), Drybulk Freight Market, Econometric Modeling, Freight Forecasting, Shipping Supply and Demand.

\section{PENDAHULUAN}

Pada saat perayaan Hari Pelayaran Internasional di tahun 2016, Koji Sekimizu sebagai Sekretaris Jenderal IMO (International Maritime Organization) mengemukakan bahwa peran pelayaran dalam perekonomian dunia amatlah penting. Menurut beliau diestimasikan bahwa $90 \%$ barang perdagangan di dunia diangkut melalui jalur laut. Transportasi laut menjadi pilihan utama dikarenakan secara relatif lebih efisien dibandingkan moda transportasi yang lain (Frankel 1989). Tentunya efisiensi tersebut akan membawa keuntungan bagi para konsumen dengan murahnya harga komoditas.

Di lain pihak, benefit yang ditanggung para pemilik kapal terkadang tidaklah semenarik dari sisi konsumen. Kebangkrutan dan kesulitan keuangan bagi perusahaan-perusahaan pelayaran tidak dapat dielakkan dalam periode belakangan ini. Pada dasarnya anggapan bahwa pelayaran adalah sebuah bisnis dengan risiko tinggi dengan tingkat pengembalian yang rendah (Patitsas 2004) memang benar adanya. Risiko tinggi yang dialami oleh perusahaan pelayaran ditenggarai akibat dari fluktuatifnya tarif angkutan pelayaran. Tarif angkutan yang merupakan pemasukan perusahaan pelayaran cenderung turun naik dan sukar diprediksi. Hal ini dikarenakan sangat tergantungnya tarif angkutan pelayaran pada keseimbangan permintaan dan penawaran akan jasa angkutan laut (Ma dalam Chen 2011). Sementara itu, permintaan dan penawaran jasa angkutan laut sendiri sangat dipengaruhi oleh berbagai macam faktor mulai dari kondisi ekonomi dunia, kejadian politik, teknologi hingga sentimen pasar.

Sektor yang paling ekstrim fluktuasi tarifnya pada industri pelayaran adalah jenis kapal curah kering, yakni jenis kapal dengan muatan khusus curah tanpa kemasan yang bersifat kering seperti batu bara, biji besi, biji nikel, gandum curah, klinker (bahan baku semen) dan lainnya. Tercatat tarif angkutan curah kering mencapai nilai terendah dan tertingginya dalam sejarah pada satu dekade belakangan ini. Pada Mei 2008 indeks BDI (Baltic Dry Index) atau indeks tarif angkutan kapal curah kering memecahkan rekor tertingginya sepanjang sejarah, namun kemudian pada Februari 2016 rekor terendahnya juga ikut terpecahkan. Baltic Dry Index adalah angka indikator ekonomi yang dikeluarkan secara harian oleh Baltic Exchange di London, namun tidak terbatas hanya pada negaranegara di laut Baltik saja. Indeks ini mengukur tarif angkutan lewat laut dengan mengambil dasar dari 26 rute pengangkutan laut di seluruh dunia yang mengangkut berbagai macam komoditi curah kering.

Fluktuasi ekstrim dari tarif angkutan curah kering akan menyulitkan bagi para pemilik kapal, tak hanya dari segi tarif angkutan yang kadang tidak sesuai dengan biaya yang ditanggung, namun harga kapal yang merupakan aset utama perusahaan juga menjadi ikut naik turun mengikuti tren tarif angkutan. Di lain pihak, kesulitan juga dialami oleh pengirim muatan yang berkepentingan untuk 
kepastian biaya logistik yang dikeluarkannya. Dikarenakan biaya tersebut akan menjadi salah satu komponen dalam penentuan harga produk mereka ke pelanggan.

Dikarenakan bisnis pelayaran merupakan sebuah bisnis global yang cenderung tanpa batas, maka efek dari fluktuasi tarif pelayaran pun turut dirasakan oleh para pelaku industri pelayaran nasional. Banyak perusahaan pelayaran nasional yang mengalami kesulitan dalam satu dekade terakhir ini, begitu pula dengan pemakai jasanya yang kerap mengalami kesulitan untuk melakukan proyeksi biaya pengiriman dalam rencana bisnisnya.

Oleh karena itu, salah satu cara untuk mengantisipasi agar tidak terjadi kerugian bisnis yang diakibatkan oleh fluktuasi tarif angkutan curah kering adalah dengan melakukan peramalan tarif. Diharapkan dengan adanya gambaran mengenai bagaimana tarif angkutan ke depannya, maka para pemangku kepentingan, baik dari sisi pemilik kapal maupun pengirim barang, dapat mengantisipasi dan mengambil keputusan yang tepat sehingga bisa meminimalisir terjadinya potensi kerugian. Oleh karena itu tujuan dari penelitian ini adalah:

1. Untuk membuat model ekonometrik dari pasar tarif angkutan curah kering berdasarkan variabelvariabel yang signifikan terhadap tarif.

2. Untuk mensimulasikan model pasar tarif angkutan curah kering dengan skenario-skenario yang telah ditentukan guna meramalkan tarif ke depannya.

\section{METODE PENELITIAN}

Penelitian ini diawali dengan melakukan studi kepustakaan pada literatur-literatur ilmiah mengenai hubungan antar variabel dalam model yang dijadikan dasar penelitian. Selanjutnya diuji korelasi pada tiap variabel yang diteliti. Rumus dari pengukuran korelasi disebut koefisien korelasi (derajat keeratan hubungan):

$\mathrm{r}=$ $\mathrm{n} \Sigma \mathrm{XY}-\left(\sum \mathrm{X}\right)(\Sigma \mathrm{Y})$

$\sqrt{ }\left(\mathrm{n} \Sigma \mathrm{X}^{2}-(\Sigma \mathrm{X})^{2} \cdot \sqrt{ }\left(\mathrm{n} \Sigma \mathrm{Y}^{2}-(\Sigma \mathrm{Y})^{2}\right.\right.$

Dimana :

$\mathrm{r} \quad=$ Nilai koefisien korelasi

$\sum \mathrm{X}=$ Jumlah pengamatan variabel $\mathrm{X}$

$\sum \mathrm{Y}=$ Jumlah pengamatan variabel $\mathrm{Y}$

$\sum \mathrm{XY}=$ Jumlah hasil perkalian variable $\mathrm{x}$ dan $\mathrm{y}$

$\left(\sum \mathrm{X} 2\right)=$ Jumlah kuadrat dari pengamatan varaibel $\mathrm{X}$

$\left(\sum \mathrm{X}\right) 2$ = Jumlah kuadrat dari jumlah pengamatan variable $\mathrm{X}$

$\left(\sum \mathrm{Y} 2\right)=$ Jumlah kuadrat dari pengamatan variable $\mathrm{Y}$

$\left(\sum \mathrm{Y}\right) 2$ = Jumlah kuadrat dari jumlah pengamatan variable $\mathrm{Y}$

$\mathrm{N}=$ Jumlah pasangan pengamatan $\mathrm{Y}$ dan $\mathrm{X}$

Hubungan kuat dan lemahnya suatu korelasi dapat diinterpretasikan dari nilai koefisiennya sebagai berikut (Sugiyono, 2007) :

$$
\begin{array}{ll}
0,00-0,199 & =\text { sangat rendah } \\
0,20-0,399 & =\text { rendah } \\
0,40-0,599 & =\text { sedang } \\
0,60-0,799 & =\text { kuat } \\
0,80-1,000 & =\text { sangat kuat }
\end{array}
$$


Dari kesimpulan penelitian deskriptif dihasilkan pemahaman mengenai variabel-variabel yang berpengaruh pada pembentukan pasar tarif angkutan pelayaran curah kering, dimana variabelvariabel tersebut menjadi dasar dalam peramalan tarif di masa depan. Adapun peramalan nantinya dicoba dijalankan pada model simulasi sistem dinamik, namun sebelumnya dilakukan permodelan statistik guna menjadi input pada model simulasi yang menggambarkan hubungan antar variabel. Permodelan statistik ini menggunakan analisa regresi berganda, dengan variabel independen adalah index tarif angkutan curah kering, sedangkan variabel dependen nya adalah semua variabel yang mempunyai korelasi kuat hingga sangat kuat.

Model dari analisa regresi berganda dibentuk berdasarkan model keseimbangan penawaran dan permintaan dari Norbulk Model yang dihasilkan dari penelitian Strandenes dan Wergeland (1981).

$$
\begin{aligned}
& Q_{\text {dem }}=Q_{\text {sup }} \\
& f(Q d, F r)=f(K, B) \\
& F r=f(Q d, K, B)
\end{aligned}
$$

dimana:

Qd didapatkan dari fungsi GDP dunia dengan formula :

$$
Q d_{t}=f\left(G D P_{t}\right)
$$

dimana:

Qd = Jumlah Permintaan Jasa Angkutan Pelayaran Muatan Curah Kering (Tonmil)

GDP = Tingkat GDP Dunia (Poin)

$\mathrm{t} \quad=$ Tahun $\mathrm{t}$

K didapatkan dengan formula :

$$
K_{t}=K_{t-1}+S D_{t}-\left(S S c_{t}+S S l_{t}\right)
$$

dimana:

$\mathrm{K}=$ Jumlah Kapasitas Kapal (Juta dwt)

$\mathrm{SD}=$ Jumlah Kapasitas Kapal Baru

SSC = Jumlah Kapasitas Kapal yang dibesituakan

SSl = Jumlah Kapasitas Kapal yang hilang/rusak

$\mathrm{t} \quad=$ Tahun $\mathrm{t}$

Untuk B, diambil harga bahan bakar Marine Gas Oil atau High Speed Diesel rata-rata selama setahun basis loading point Singapura.

Dalam penelitian ini validasi diadakan melalui tiga cara, yaitu yang pertama validasi model dengan statistik uji perbandingan rata-rata (mean comparison) dan uji perbandingan variasi amplitude (percentage of error variance) (Barlas, 1989). 
Mean Comparison

$$
E 1=\frac{|\bar{S}-\bar{A}|}{\bar{A}}
$$

$\bar{S}=$ Nilai rata-rata hasil simulasi

$\bar{A}=$ Nilai rata-rata data

Dimana model dapat dianggap valid apabila E1 $\leq 5 \%$

Percentage of Error Variance

$$
E 2=\frac{|S s-S a|}{S a}
$$

Ss $=$ Standar Deviasi Model

$S a=$ Standar Deviasi Data

Dimana model dianggap valid apabila E2 $\leq 20 \%$.

Selain itu metode pengujian validasi juga dilakukan dengan menggunakan Mean Absolute Percentage Error (MAPE) yang sudah umum untuk pengujian model peramalan.

$$
\sum_{t=1}^{n}\left|\frac{(Y t-\bar{Y} t)}{Y t}(100)\right| \mathrm{n}
$$

Yt $=$ Nilai Riil

$\overline{\mathrm{Y}} \mathrm{t}=$ Nilai Hasil Simulasi

$\mathrm{n}=$ Jumlah variabel yang diamati

Untuk peramalan nanti, pada model akan diskenariokan beberapa perubahan pada variabel Qd (Jumlah komoditas curah kering yang diperdagangkan via laut), K (Jumlah kapasitas kapal yang tersedia) dan Harga Bahan Bakar (B). Adapun detail mengenai skenario tersebut dapat dilihat pada

\begin{tabular}{|c|c|c|c|}
\hline Jenis Skenario & Pertumbuhan Ekonomi & Harga Bahan Bakar & Pertumbuhan Kapal \\
\hline Optimis & $\begin{array}{l}3,5 \% \text { pada tahun } 2017 \\
\text { dan 3,8\% per tahun } \\
\text { untuk seterusnya }\end{array}$ & $\begin{array}{l}\text { Mengikuti Pola Tren } \\
\text { Pertumbuhan sejak tahun } \\
2000 \text { (10,59\% per tahun) }\end{array}$ & $\begin{array}{l}\text { 0\% (Dicetuskan Oleh } \\
\text { Dreyfus pada tahun 2016) }\end{array}$ \\
\hline Sedang & $\begin{array}{l}\text { 3,5\% pada tahun } 2017 \\
\text { dan 3,8\% per tahun } \\
\text { untuk seterusnya }\end{array}$ & $\begin{array}{l}\text { Mengikuti Pola Tren } \\
\text { Pertumbuhan sejak tahun } \\
2000(10,59 \% \text { per tahun })\end{array}$ & $\begin{array}{l}\text { Mengikuti Pola Tren } \\
\text { Pertumbuhan sejak tahun } \\
2000 \text { (6,7\% per tahun) }\end{array}$ \\
\hline
\end{tabular}
Tabel 1.

Tabel 1 Skenario Model Dinamik

\section{HASIL DAN PEMBAHASAN}

\section{Variabel Penentu Pembentukan Tarif}

1. Variabel Penentu dari Sisi Permintaan

1. Tingkat Perekonomian Dunia

GDP (Gross Domestic Product) adalah indikator dari perkembangan ekonomi suatu negara, sedangkan untuk melihat perkembangan ekonomi dunia indikator yang digunakan adalah dengan melihat angka total dari seluruh GDP negara-negara yang ada di dunia. Hubungan antara tingkat perekonomian dunia dengan jumlah komoditas curah kering yang 
diperdagangkan melalui laut sangat signifikan, dari data tahun 1991 hingga 2016 menunjukkan bahwa koefisien korelasi laju pertumbuhan GDP dengan laju pertumbuhan jumlah barang yang diperdagangkan via laut mencapai 0,85 .

2. Perdagangan Komoditas melalui Laut

Komoditas curah kering merupakan salah satu komoditas terbesar yang diperdagangkan melalui transportasi laut, data dari tahun 1991 hingga 2016 memperlihatkan bahwa perbandingan muatan curah kering terhadap total komoditas yang diangkut melalui laut sekitar 40\%. Hal ini dikarenakan mayoritas muatan curah kering adalah komoditas bahan mentah yang menjadi material utama dalam perdagangan. Data juga menunjukkan bahwa koefisien korelasi antara volume komoditas curah kering yang diperdagangkan melalui laut dengan GDP dunia mencapai 0,99.

2. Variabel Penentu dari Sisi Penawaran

a. Armada Kapal Curah Kering

Kim (2013) menyebutkan armada kapal adalah faktor utama dari sisi penawaran pada industri pelayaran. Dari sisi ekonomi dimana semua situasi yang terjadi pada pasar dianalisa berdasarkan hukum permintaan dan penawaran, jumlah kapal yang tersedia di industri pelayaran curah kering akan memberikan efek kepada titik ekuilibrium di pasar tarif. Sejak tahun 2000 jumlah kapal curah kering meningkat cukup tajam dengan rata-rata laju penambahan kapasitas daya angkutnya mencapai $6,7 \%$ per tahunnya.

b. Produktivitas Armada dan Harga Bahan Bakar

Menurut Stopford (2009) salah satu faktor penentu produktivitas kapal adalah kecepatan Kapal, penjelasannya adalah ketika kapal berjalan dengan kecepatan yang tinggi, maka waktu berlayar akan lebih singkat, dan kapal bisa mengangkut muatan lebih sering dan lebih banyak sehingga produktivitas kapal pun ikut bertambah. Namun salah satu efek dari penambahan kecepatan kapal ini adalah biaya bahan bakar, dimana pada kecepatan tinggi tentunya akan memakan bahan bakar yang cukup besar juga, dan biaya bahan bakar mencapai $40 \%$ dari seluruh biaya total dalam pelayaran. Sehingga jika tarif angkutan sedang tinggi di pasar maka para pemilik kapal akan cenderung untuk memerintahkan armadanya untuk menambah kecepatannya sehingga jumlah penawaran kapal secara jangka pendek akan bertambah, namun jika harga bahan bakar sedang naik tetapi tarif angkutan kenaikannya tidak signifikan maka para pemilik kapal akan cenderung melakukan slow steaming atau penurunan kecepatan kapal untuk menghemat bahan bakar (German dan Smith, 2012), yang tentunya akan menurunkan jumlah penawaran kapal.

\section{Hubungan antara Indeks Tarif Angkutan (BDI) dengan Variabel Penentunya}

1. Hubungan Indeks Tarif Angkutan (BDI) dengan Variabel dari sisi permintaan

Data sepanjang tahun 1991 hingga 2016 seperti pada Gambar 1 menunjukkan bahwa koefisien korelasi antara jumlah permintaan akan jasa transportasi laut dengan indeks harga ternyata tak sampai 5\% atau kurang signifikan. Terutama semenjak tahun 2003, dimana pergerakan indeks semakin tidak sesuai dengan jumlah total permintaan, Hal ini juga pernah menjadi concern penelitian sebelumnya yang dilakukan oleh Chen et al. (2012), dimana tarif angkutan curah kering menunjukkan gejala fluktuasi yang tidak lazim pada tarif sejak tahun 2003. 


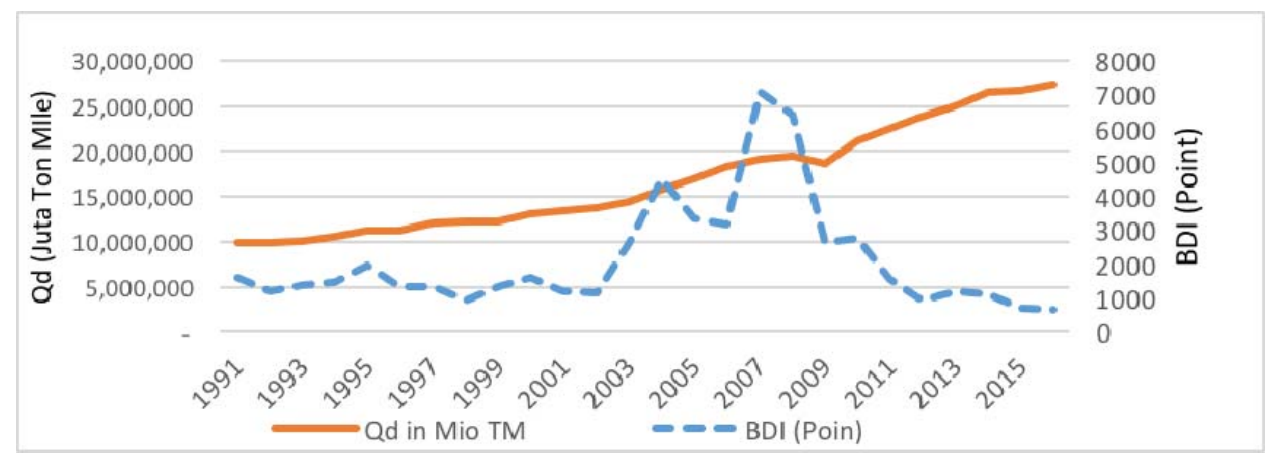

Sumber : Fearnleys Shipping Reports (akses Juli 2017) dan Llyods Shipping Reports (akses April 2017)

Gambar 1 Hubungan antara Indeks Tarif dengan Jumlah Permintaan Jasa Angkutan

\section{Hubungan Indeks Tarif Angkutan (BDI) dengan Variabel dari sisi penawaran}

Jumlah kapasitas armada yang tersedia adalah unsur utama yang mempengaruhi tarif dari sisi penawaran, kenaikan dari jumlah armada yang ada di industri akan menaikkan jumlah penawaran (Tinbergen, 1959), dan ketika penawaran melebihi jumlah permintaan akan jasa pelayaran maka tarif akan turun dan tarif akan kembali naik jika jumlah kapal yang ditawarkan bisa menyesuaikan dengan jumlah permintaannya, kesimpulannya tarif dengan jumlah kapal mempunyai hubungan berbanding terbalik.

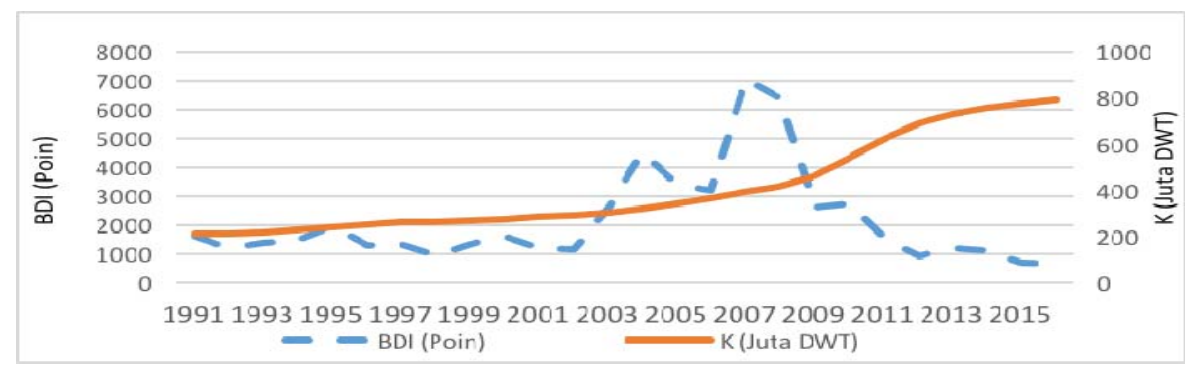

Sumber : Llyods Shipping Reports (akses April 2017) dan Clarksons (akses Januari 2017)

Gambar 2 Hubungan antara Jumlah Kapasitas Kapal (K) dengan Indeks Tarif (BDI)

Namun dari Gambar 2 terlihat bahwa teori tersebut tidak selalu benar, seperti pada tahun 2002 hingga 2005 meskipun jumlah kapal selalu bertambah BDI pun ikut naik, hal ini terjadi kembali di tahun 2006 hingga 2008, fenomena tersebut bisa dijelaskan bahwa selain tarif tidak dipengaruhi oleh jumlah kapasitas kapal saja, tetapi pengaruh permintaan juga turut mempengaruhi perubahan tarif angkutan, hal lain yang dapat menjelaskan hal ini adalah adanya jeda waktu dari penawaran untuk mengejar permintaan.

Selain dari jumlah kapasitas kapal, variabel lain yang turut mempengaruhi jumlah penawaran adalah bahan bakar yang erat kaitannya dengan produktivitas kapal, bahan bakar kapal atau bunker. Koefisien Korelasi antara bahan bakar dengan indeks tarif adalah 0,29. Meskipun ada kecenderungan korelasi kedua variabel ini cukup erat terutama pada periode sebelum tahun 2009, namun pada tahun berikutnya sampai saat ini meskipun harga bahan bakar mengalami kenaikan signifikan tetapi para pemilik kapal tidak dapat menaikkan tarifnya karena persaingan, akibatnya pada periode 2009 hingga 2015 perusahaan pelayaran banyak mengalami kesulitan keuangan bahkan mencapai kebangkrutan dikarenakan mereka tidak dapat menutupi biaya operasionalnya. 


\section{Evaluasi Hubungan antara Indeks Tarif dengan Variabel Independennya}

Dalam penelitian ini data time series yang dipergunakan akan dirubah dahulu ke dalam bentuk logaritma natural, dengan maksud untuk menstabilkan variabel yang non stasioner dan juga data akan menjadi linier setelah ditransformasikan, sehingga akan mempermudah dalam penganalisaannya.

Hasil koefisien korelasi dari masing-masing variabel dependen ternyata menunjukkan hasil yang kurang signifikan terhadap variabel independen terlihat pada Tabel 2. Oleh karena itu perlu dijelaskan dengan membuat model statistik dengan metode regresi berganda yang dapat menggambarkan hubungan secara keseluruhan.

Tabel 2 Koefisien Korelasi

\begin{tabular}{lc}
\hline & Indeks Tarif Angkutan (BDI) \\
\hline Indeks Tarif Angkutan (BDI) & 1 \\
Jumlah Permintaan (Qd) & 0,049 \\
Jumlah Kapasitas Kapal (K) & $-0,137$ \\
Harga Bahan Bakar (B) & 0,295 \\
\hline
\end{tabular}

\section{Permodelan}

1. Model Regresi

Analisa regresi berganda digunakan juga untuk membentuk model pembentukan tarif angkutan curah kering dari variable-variabel independen yakni Jumlah Permintaan Jasa Angkutan (Qd), Jumlah Kapasitas Kapal yang tersedia (K) serta harga bahan bakar (B), dengan hasil pada Tabel 3.

Tabel 3 Model Regresi Berganda Indeks Tarif Angkutan (BDI) dengan Jumlah Permintaan Jasa (Qd), Kapasitas Kapal (K) dan Harga Bahan bakar (B)

\begin{tabular}{crrrr}
\hline \multicolumn{1}{c}{ Variable } & Coefficient & Std. Error & t-Statistic & Prob. \\
\hline LN(B) & 0,809468 & 0,168264 & 4,810710 & 0,0001 \\
LN(K) & $-5,020842$ & 0,629955 & $-7,970165$ & 0,0000 \\
LN(Qd) & 5,051709 & 0,919900 & 5,491587 & 0,0000 \\
C & $-51,38173$ & 11,32489 & $-4,537063$ & 0,0002 \\
& & & & \\
\hline$R$-squared & 0,826267 & Mean dependent var & 7,453780 \\
Adjusted $R$-squared & 0,802576 & S.D. dependent var & 0,616318 \\
S.E. of regression & 0,273845 & Akaike info criterion & 0,388128 \\
\hline
\end{tabular}

$\mathrm{R}^{2}$ sebesar 0,8263 artinya kemampuan variabel independen (B, K, Qd) dalam menerangkan varians variabel dependen (I) sebesar $82,63 \%$ atau dapat diartikan sebesar $82,63 \%$ variabel I dipengaruhi oleh variabel $\mathrm{B}, \mathrm{K}$, dan Qd, sisanya $17,27 \%$ dipengaruhi oleh variabel lain di luar model (selain B, K, Qd).

\section{MODEL REGRESI:}

$$
(\ln ) \mathrm{I}_{\mathrm{t}}=-51,38+0,809(\ln ) \mathrm{B}_{\mathrm{t}}-5,02(\ln ) \mathrm{K}_{\mathrm{t}}+5,05(\ln ) \mathrm{Qd}_{\mathrm{t}}+\quad \mathrm{t}
$$

\section{Validasi Model}

Dari uji validitas E1(Mean Comparison) yang didapatkan adalah sebesar 3,74\% atau masih di bawah ambang batas yakni E1 di bawah 5\%. Untuk E2 (Percentage Error Variance) adalah $15,14 \%$, masih di bawah ambang batas untuk E2 yakni di bawah $20 \%$. 
Meskipun secara uji validitas model menunjukkan hasil yang memuaskan namun jika dilihat secara mendetail maka terlihat ada beberapa simpangan cukup besar yang terjadi pada kurun waktu tertentu, dimana kurun waktu 2000 hingga 2012 menunjukkan simpangan tersebut, nilai Mean Absolute Percentage Error untuk nilai BDI adalah sebesar 20,40\% (detail grafik bisa dilihat pada Gambar 5), sehingga untuk model ini jika dikaitkan dengan kriteria masuk ke golongan cukup, dikarenakan nilai MAPE di kisaran 20 hingga 50\% (Lewis, 1982).

Ditenggarai dalam model hal-hal seperti ini sulit dipetakan karena adanya faktor psikologis dari para pelaku industri dalam mempersepsikan perekonomian ke depannya, hal kualitatif seperti inilah yang tidak dapat digambarkan dalam model, namun secara garis besar dan tanpa adanya intervensi kualitatif tersebut, model sudah cukup untuk menggambarkan pembentukan indeks tarif angkutan curah kering dan dapat digunakan dalam meramalkan tarif ke depannya dengan berbagai macam skenario pada variabel yang mempengaruhinya.

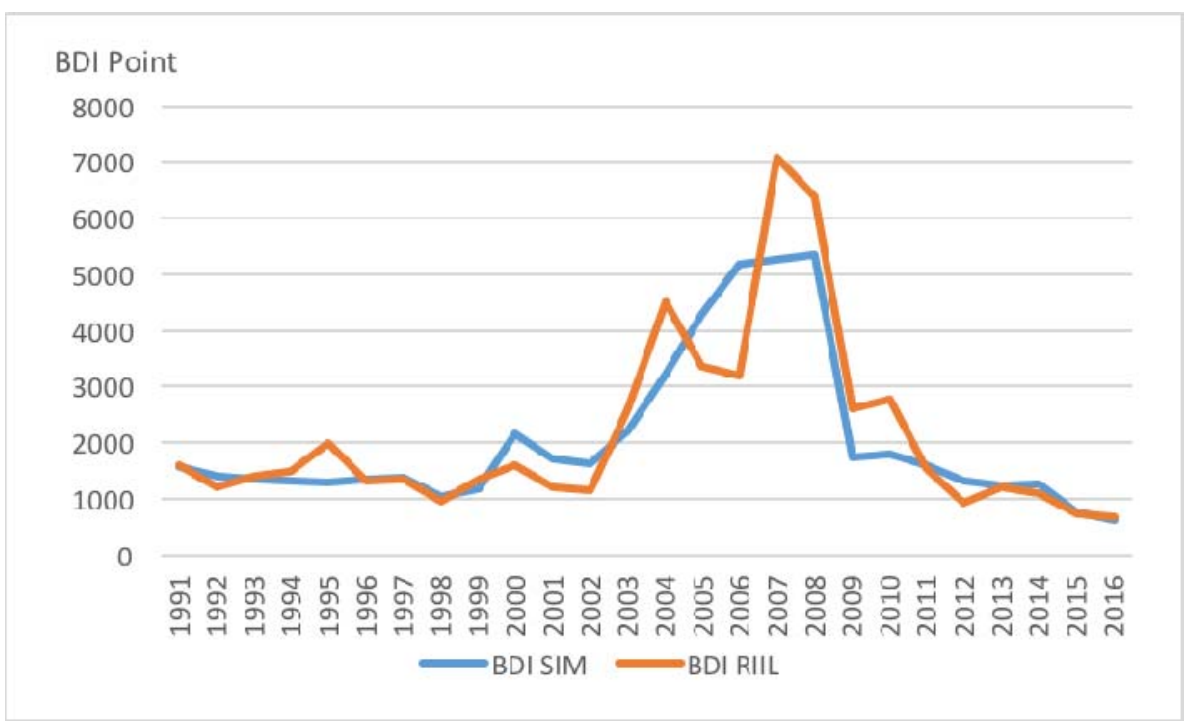

Gambar 3 Grafik Perbandingan BDI Simulasi dengan Riil

\section{Skenario dan Hasil}

Sebelum menjalankan skenario guna meramalkan nilai indeks tarif ke depannya, maka dilakukan peramalan Qd terlebih dahulu. Qd sendiri menurut Stopford (2009) merupakan fungsi dari GDP dunia. Model regresi sederhananya adalah:

$\mathrm{Qd}=-5315527,117+137876,814$ GDP

Hasil dari kedua model skenario dapat dijelaskan pada Gambar 4 sebagai berikut. 


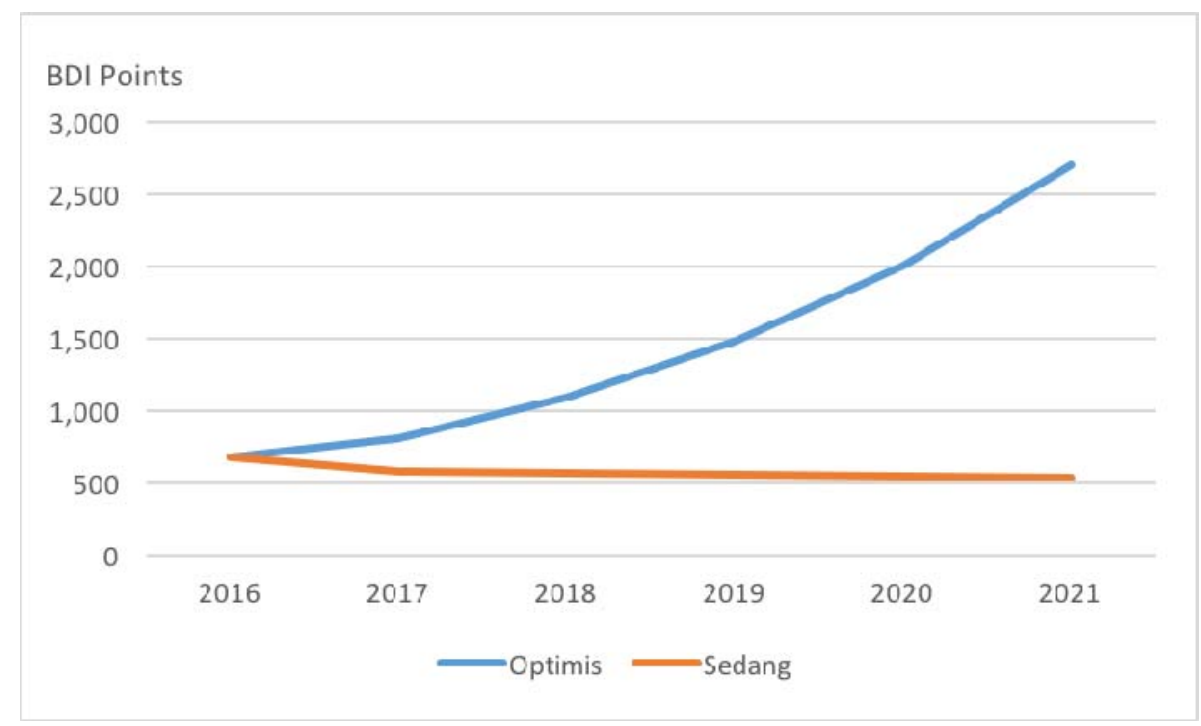

Gambar 4 Simulasi BDI dengan skenario Optimis dan Sedang

Dengan menggunakan asumsi yang sama pada variabel bahan bakar (B) dan variabel jumlah perdagangan ekonomi dunia (Qd), namun ada perbedaan pada laju penambahan kapal. Pada skenario optimis dengan laju penambahan kapal 0\%, mulai tahun 2017, indeks tarif (BDI) mulai mengalami kenaikan dikarenakan adanya percepatan laju kenaikan dari sisi permintaan, adapun dari sisi penawaran ditekan supaya tetap tidak ada perubahan, artinya jumlah kapal baru diasumsikan sama dengan jumlah kapal yang di scrap. Pada skenario optimis BDI pada tahun pertama melonjak drastis hampir 20\% dari tahun sebelumnya. Berdasarkan wawancara dengan para pelaku industri di dunia pelayaran, dengan melihat kondisi perekonomian pada saat ini, indeks rata-rata 2000 poin merupakan titik visible yang ingin dicapai. Pada simulasi dengan skenario optimis diharapkan indeks akan terus naik hingga mencapai nilai tersebut pada tahun 2020 .

Untuk skenario sedang atau normal, asumsi perekonomian sama dengan skenario sebelumnya tetapi dengan harga bahan bakar dan jumlah kapasitas kapal bertambah mengikuti tren yang ada. Dari grafik terlihat bahwa indeks tarif terus mengalami tekanan karena jumlah kapal yang membanjiri pasar tidak sesuai dengan daya serap dari sisi permintaannya. Dengan laju pertumbuhan kapal sebesar 6,7\% per tahunnya akan mengakibatkan turunnya indeks tarif rata-rata sebesar $4,5 \%$ per tahunnya. Sehingga jika tidak ada upaya untuk melakukan penyesuaian jumlah kapal yang beredar maka indeks tarif akan mengalami kesulitan untuk rebound atau kembali ke nilai yang diinginkan oleh industri.

\section{KESIMPULAN DAN SARAN}

\section{Kesimpulan}

1. Berdasarkan analisa dari model pasar tarif angkutan yang digunakan dalam penelitian ini, semuanya menunjukkan bahwa faktor permintaan dan penawaran akan jasa pelayaran memainkan peranan penting dalam pembentukan tarif angkutan, namun faktor-faktor tersebut tidak mempunyai pengaruh dominan terhadap pembentukan tarif jika secara individu, semua faktor yang dianalisa dalam penelitian ini (baik dari sisi permintaan maupun penawaran) harus serentak dipergunakan baru dapat menjelaskan bagaimana tarif terbentuk. Terlihat dari koefisien korelasi antara indeks tarif dengan Jumlah Permintaan hanya 0,0492, sedangkan koefisien korelasi antara indeks tarif dengan jumlah kapasitas kapal yang tersedia hanya $-0,14$ dan juga untuk koefisien korelasi antara harga bahan bakar dengan indeks tarif hanya 0,295. Namun jika 
ketiga faktor tersebut serentak dipergunakan pada model koefisien adjusted $R^{2}$ nya mencapai 0,82 .

2. Model sistem dinamik yang didapat dari penelitian ini memiliki nilai MAPE cukup besar yakni 20\%, yang berarti pada model bisa terjadi bias angka plus minus 20\% dari output model, tetapi jika diukur secara Mean Comparison dan Percentage Error Variance, model mempunyai skor masing-masing 3,742\% dan 15,14\%, yang berarti model masih dapat diterima. Kemudian model dijalankan dengan dua skenario yang telah ditetapkan, yakni skenario normal dengan laju penambahan kapal tetap seperti kondisi saat ini, dan skenario optimis dengan laju penambahan kapal di nol kan, artinya jumlah kapal yang keluar sama dengan yang masuk. Hasilnya dari kedua skenario tersebut terlihat bahwa skenario optimis lebih menjanjikan yakni pada tahun 2017 mulai terjadi recovery dan pada tahun 2020 indeks tarif sudah mencapai rata-rata normalnya.

\section{Saran}

1. Perlunya rentang data yang lebih panjang, dikarenakan adanya keterbatasan peneliti dalam mengumpulkan data yang diperoleh sehingga data tahunan dari tahun 1991 hingga 2016 dirasakan masih kurang cukup untuk diolah karena dalam pendekatan statistik banyaknya jumlah data turut mempengaruhi hasil dan realibilitas dari model.

2. Mengingat beberapa penelitian sebelumnya telah terbukti adanya hubungan yang kuat antara empat pasar utama dalam industri pelayaran, maka sebaiknya penelitian selanjutnya bisa mengakomodir tiga pasar lainnya yang tidak dibahas dalam penelitian ini, sehingga dalam model dinamik bisa ditambahkan pergerakan ketiga pasar lainnya yang saling mempengaruhi.

\section{DAFTAR PUSTAKA}

Barlas Y. 1989. Multiple tests for validation of system dynamics simulation models. European Journal of Operational Research. 42(1): 59-87.

Chen S. 2011. Modelling and forecasting in the dry bulk shipping market [Disertasi]. Delft (NL): Delft University of Technology.

Chen S, Meersman H, Voorde EV. 2012. Forecasting spot rates at main routes in the dry bulk market. Maritime Economics and Logistics. 14(4): 498-537

Dreyfus L. 2016. Road to recovery for the Drybulk Market. BIMCO Market Analysis Ed. May 2016, Bagsvaerd (DK): BIMCO.

Frankel EG. 1989. Shipping and its role in economic development. Maritime Policy. 13(1): 22-42.

German H, Smith Wo. 2012. Shipping markets and freight rates. an analysis of the Baltic Dry Index. The Journal of Alternative Investments. 15(1): 98-109

Kim KH. 2013. Forecasting the capesize freight market [Disertasi]. Malmo (SE): World Maritim University.

Lewis C. 1982. Industrial and Business Forecasting Methods. London (UK): Butterworth Scientific.

Patitsas LS. 2004. Shipping; is it a high risk low return business?. [Thesis]. Cambridge (US): Massachusetts Institute of Technology.

Stopford M. 2009. Maritime Economics (4th ed). London (UK): Routledge.

Sugiyono. 2007. Metode Penelitian Bisnis. Bandung (ID): CV. Alfabeta.

Strandenes SP, Wergeland T. 1981. Ecotank SAF [Working paper]. Bergen (NO): Norwegian School of Economics and Business Administration. 
Tinbergen J. 1959. Tonnage and freight. Jan Tingergen Selected Papers, eds. L.H. Klaassen. Amsterdam (NL): North-Holland Publishing Company.

Lampiran 1 Data yang dipergunakan dan Transformasi nya ke Logartima Natural

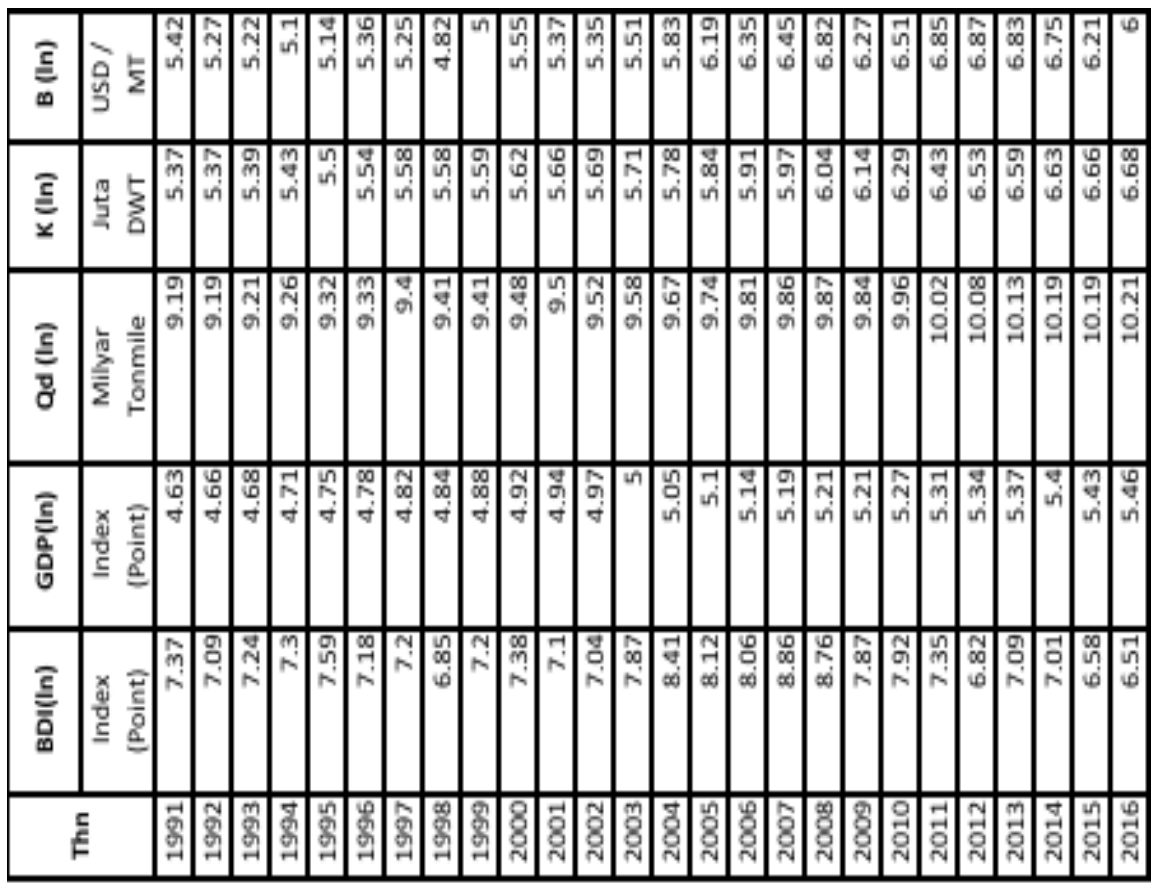

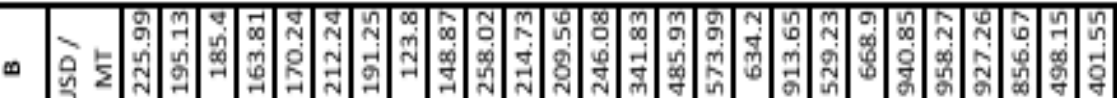

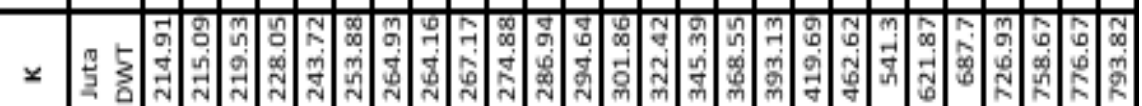

\begin{tabular}{|c|c|c|c|c|c|c|c|c|c|c|c|c|c|c|c|c|c|c|c|c|c|}
\hline 8 & 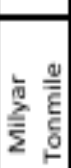 & 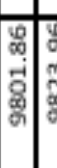 & $\begin{array}{l}0 \\
0 \\
0 \\
0\end{array}$ & & 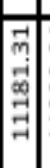 & 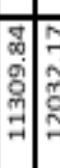 & 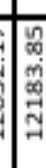 & ปี & 苟 & 政 & g & जै & & 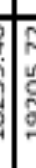 & & 匇 & & 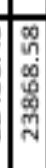 & & & \\
\hline ò & 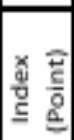 & 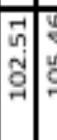 & & 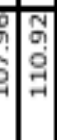 & ज़े & 拿 & $\begin{array}{l}9 \\
0 \\
0\end{array}$ & $\underline{n}$ & 奋 & : & 8 & $\begin{array}{l}\infty \\
0 \\
0\end{array}$ & & 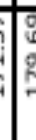 & هُ & 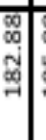 & & 贶 & & & \\
\hline ב̄ & 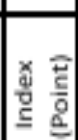 & 年 & & 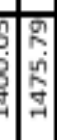 & 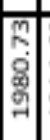 & 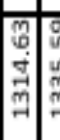 & 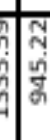 & 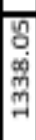 & 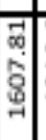 & 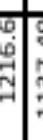 & \% & 乌ి & & 8 & ल. & 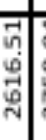 & & 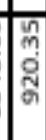 & 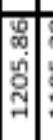 & 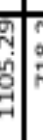 & \\
\hline & & 馬 & תู & 素 & & 9 & & & & & & & & & & & & & & 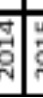 & \\
\hline
\end{tabular}


Lampiran 2 Validasi BDI Model Sistem Dinamik

\begin{tabular}{|c|c|c|c|}
\hline Tahun & BDI SIM & BDI RIIL & ABS Error \\
\hline 1991 & 1581 & 1591 & $1 \%$ \\
\hline 1992 & 1414 & 1201 & $18 \%$ \\
\hline 1993 & 1347 & 1400 & $4 \%$ \\
\hline 1994 & 1316 & 1476 & $11 \%$ \\
\hline 1995 & 1300 & 1981 & $34 \%$ \\
\hline 1996 & 1341 & 1315 & $2 \%$ \\
\hline 1997 & 1361 & 1336 & $2 \%$ \\
\hline 1998 & 1034 & 945 & $9 \%$ \\
\hline 1999 & 1170 & 1338 & $13 \%$ \\
\hline 2000 & 2169 & 1608 & $35 \%$ \\
\hline 2001 & 1710 & 1217 & $41 \%$ \\
\hline 2002 & 1636 & 1137 & $44 \%$ \\
\hline 2003 & 2221 & 2617 & $15 \%$ \\
\hline 2004 & 3212 & 4510 & $29 \%$ \\
\hline 2005 & 4280 & 3371 & $27 \%$ \\
\hline 2006 & 5164 & 3180 & $62 \%$ \\
\hline 2007 & 5255 & 7071 & $26 \%$ \\
\hline 2008 & 5337 & 6390 & $16 \%$ \\
\hline 2009 & 1744 & 2617 & $33 \%$ \\
\hline 2010 & 1787 & 2758 & $35 \%$ \\
\hline 2011 & 1587 & 1549 & $2 \%$ \\
\hline 2012 & 1328 & 920 & $44 \%$ \\
\hline 2013 & 1233 & 1206 & $2 \%$ \\
\hline 2014 & 1258 & 1105 & $14 \%$ \\
\hline 2015 & 750 & 718 & $4 \%$ \\
\hline 2016 & 629 & 673 & $7 \%$ \\
\hline AVERAGE & 2045 & 2124 & $20.40 \%$ \\
\hline STDEV & 1390 & 1638 & \\
\hline
\end{tabular}

Mean Comparison untuk BDI : [(2124 - 2045)/2124] = 3,74 \%

Mean Aboslute Percentage Error (MAPE) untuk BDI : Rata-rata dari ABS Error = 20,40 \% Percentage Error Variance untuk BDI : [(1638 - 1390)/1638] = 15,14 \% 